José Marçal Jackson Filho ${ }^{1}$ Ada Ávila Assunção ${ }^{2}$

\title{
Trabalho em teleatendimento e problemas de saúde
}

\author{
Work in telemarketing and related health \\ problems
}

${ }^{1}$ Editor científico

${ }^{2}$ Editora convidada
As situações de trabalho existentes nas indústrias de processo contínuo foram consideradas, nos anos de 1980, como laboratórios naturais para o estudo da cognição no trabalho (KEYSER, V. L'ergonomie de processus continus: de la contingence à la complexité - l'évolution dês idées dans l'étude des processus continus. Le Travail Humain, v. 51, n. 1, p. 1-18, 1988). Os mecanismos cognitivos implementados pelos operadores e o desenvolvimento de suas inteligências para operar, a partir de salas de controle, processos de produção de funcionamento complexo e de alto risco foram estudados e trouxeram contribuições para diferentes áreas do conhecimento, como Ergonomia, Psicologia, Sociologia do Trabalho, Engenharias de Automação e de Produção, entre outras.

As pesquisas realizadas no setor de teleatendimento no século XXI mostram que as situações de trabalho estudadas podem ser consideradas uma espécie de antítese do que se encontrou nas salas de controle das indústrias de processo nos anos de 1980.

O traço comum dos artigos que compõem este número temático da Revista Brasileira de Saúde Ocupacional, além do interesse de seus autores pela saúde dos trabalhadores, é certa estupefação quanto às formas de organização existentes nos serviços de teleatendimento, cujos modos de gestão são voltados para impedir o desenvolvimento da inteligência, da emoção, da sociabilidade humanas em atividades de trabalho. Fica exposto o paradoxo: de um lado, a natureza do trabalho, que diz respeito à interação usuário-teleatendente; do outro, as regras rígidas de gestão, as quais cerceiam as expressões necessárias à interação inerente ao processo de comunicação humana... Diante desse paradoxo organizacional, como não adoecer?

Ao contrário da esperada qualidade no contexto vivo do trabalho, observam-se, nos ambientes virtuais, o empobrecimento do trabalho e o sofrimento das pessoas envolvidas. Como, nas situações descritas por esta coletânea, desejar a eclosão da inteligência dos trabalhadores? Os autores examinam os efeitos de uma organização do trabalho que estabelece métodos de gestão voltados para avaliar, punir e premiar a reserva de inteligência dos indivíduos.

Os serviços de teleatendimento, considerados vitais para o desenvolvimento das empresas na nova estrutura da produção e da economia, tornaram-se viáveis graças à junção das tecnologias da telefonia e da informática. Pode-se, no entanto, afirmar que, em sua prática, incorporaram princípios neotayloristas que se baseiam em formas de controle exacerbadas do tempo e das interações. Os gestores buscam implicar a subjetividade dos trabalhadores em prol dos objetivos comerciais e econômicos das empresas, característica que transformou o setor em emblema do processo mundial de intensificação do trabalho. Aparentemente natural, o modelo organizacional em teleatendimento utiliza 
a hora uniforme do relógio como medida do trabalho cuja natureza é subjetiva e emocional.

A organização do trabalho nas empresas reproduz em seus métodos de gestão o mundo das idealidades matematicamente subestruturadas de Galileu, cientista que, ao final da Idade Média, reforçou a evidência recebida dos gregos de que podemos medir o espaço - as distâncias, as áreas e os volumes, definindo praticamente a tarefa da Ciência Moderna como a tarefa de aprender a medir o mundo, expressando-o em fórmulas matemáticas (MARQUES, I. C. Desmaterialização e trabalho. In: LASTRES, H. M. M.; ALGABLI, S. (orgs.). Informação e globalização na era do conhecimento. Rio de Janeiro: Campus, 1999. p. 191-215).

Constitui-se em fato curioso a forma como as técnicas de representação do tempo e do espaço tridimensional em que vivemos no mundo bidimensional do papel - os números, as tabelas, os horários, as fórmulas, os desenhos, os mapas, os roteiros e os planos - são cultivadas no mundo pós-moderno, na era informacional, justamente para controlar o trabalho daqueles cuja inteligência é o móvel da produção.

Lembrando Lévy (O que é virtual? São Paulo: 34, 1996), o trabalho é um saber alimentado, uma competência virtual que se atualiza, um saber-devir... Continua o autor: "Como aplicar os sistemas de medida que acompanham essa mutação?” É ainda Lévy que pergunta: "Quando irão as instituições e as mentalidades acolher os conceitos adequados?" Acrescentamos: Como o poder público poderá transformar esta realidade?

A separação física existente na relação de serviço estabelecida entre o usuário e o trabalhador de empresa de prestação de serviço público (ou privado) ou de empresa subcontratada é um componente do trabalho de teleatendimento que perturba a interação entre os dois pólos da comunicação. A interação, agora por telefone, traz consigo conseqüências aos trabalhadores que se encontram na interface (front office) entre a prestadora dos serviços e os usuários, mas não possuem necessariamente os meios para resolver os problemas dos usuários, uma vez distantes dos serviços técnicos propriamente ditos (back office) e submetidos a controle estrito da hierarquia. Além disso, para ter vantagens salariais ou receber prêmios, são levados a oferecer aos usuários serviços e produtos de eficiência duvidosa ou desnecessários.

O trabalhador vive a contradição entre, por um lado, interagir e não poder interagir, dado o intenso controle do tempo e da própria interação, e, de outro, a perda de sentido de seu trabalho, uma vez que, para ganhar a vida (e os prêmios estimulados pela gestão) é preciso prejudicar outrem e sofrer os efeitos negativos contra si mesmo dos atos realizados nas operações (a mentira, por exemplo). $\mathrm{O}$ trabalho de teleatendimento não pode se tornar uma "obra" nos termos de Meyerson (Les fonctions psychologiques et les oeuvres. Paris: PUF, 1948), a qual estaria na base do desenvolvimento da personalidade dos trabalhadores; ao contrário, em sua base localiza-se a fonte de adoecimento e da alienação dos indivíduos.

É mister, contudo, ressaltar que alguns serviços essenciais à comunidade são prestados por meio do teleatendimento. Nesse tipo de situação, a interação entre teleatendente-usuário está na origem da necessária ação pública, cuja efetividade depende da qualidade da interação por telefone.

Apesar das evidências científicas, não há consenso social a respeito dos malefícios desse sistema, embora seja conhecida a associação entre "trabalhos intensificados", doenças musculoesqueléticas e distúrbios do comportamento, como mostram recentes pesquisas européias sobre condições de trabalho e saúde.

As pesquisas deste número da RBSO tratam diferentes facetas do trabalho em teleatendimento, valendo-se de diversas abordagens metodológicas e de disciplinas variadas. Se, de um lado, a estupefação ante a violência contida nos modos de gestão e de orga- 
nização de algumas empresas, como dito anteriormente, é explícita em vários artigos, de outro, a qualidade da descrição da realidade do trabalho ou de sua percepção pelos teleatendentes, também presente nos trabalhos deste número, é essencial para a transformação das situações de teleatendimento e para a adoção de medidas de prevenção ao adoecimento. A partir dos resultados destas pesquisas, novos desenhos de programas de prevenção e novas bases para ações públicas podem ser definidos. Dito de outro modo, a prevenção ao adoecimento será efetiva caso supere os paradigmas tradicionais, os quais são baseados na ação sobre os indivíduos, rumo a políticas que levem em conta o conhecimento do trabalho e dos modos operatórios implementados pelos trabalhadores.

Esperamos, assim, que este número temático contribua no esforço conjunto, que reagrupa interesses acadêmicos, sindicais e do poder público sintonizados para enfrentar o desafio posto aos sistemas de saúde pública e para qualificarem-se a fim de identificar e monitorar efeitos potencialmente adversos sobre a saúde originados da inserção dos seres humanos nesses serviços.

Por intermédio dos fatores encontrados e das reflexões propostas, mais do que fazer a denúncia social, busca-se participar da resistência coletiva à intensificação do trabalho (In: THÉRY, L. (org.). Le travail intenable. Résister collectivement à l'intensification du travail. Paris: La Découverte, 2006), presente fortemente no setor de teleatendimento, mas não exclusiva a ele; intensificação esta que assola atualmente o mundo da produção e do trabalho, ou seja, o mundo dos homens. 